Journal Universitas Muhammadiyah Gresik Engineering, Social Science, and Health International Conference (UMGESHIC)

UMGCINMATIC : $1^{\text {st }}$ Rethinking Education during Covid-19 Era: Challange and Innovation

\title{
CONSUMER TRUST ON BUYING INTEREST IN ONLINE SHOPPING: E-COMMERCE SHOPEE
}

\author{
Author \\ Devi wahyu Hidayah" ${ }^{1}$, Asri Rejeki ${ }^{2}$, Ima Fitri Sholichah ${ }^{3}$ \\ Psychology Faculty, Universitas Muhammadiyah Gresik ${ }^{1,2,3}$ \\ Email: deviwahyuhidayah07@gmail.com ${ }^{1}$,asrirejeki@umg.ac.id ${ }^{2}$, \\ ima_fitri@umg.ac.id ${ }^{3}$.
}

\begin{abstract}
Abstract. This study aimed to determine the effect of consumer trust on buying interest in online shopping on e-commerce shopee. Low consumer confidence is a barrier to increasing buying interest in e-commerce. This causes low buying interest and the emergence of fear to make online transactions. This study is qualitative research. The participants were 97 students from the faculties of psychology, teacher training, and economics Universitas Muhammadiyah Gresik which were obtained by incidental sampling. Collecting data to measure buying interest using the adoption of a buying interest scale from Kotler, while to measure consumer confidence adopting a consumer trust scale from Daqin Lu 2017 and Dulipovici 2015. Both of these scales use a Likert scale. Test the validity of the scale using content validity. Scale reliability test using Alpha Cronbach technique. The results showed the Spearman rank test with a sig value. (2tailed) of $0.000<0.05$, indicating $\mathrm{Ha}$ is accepted, it is concluded that consumer trust has a significant effect on buying interest. The correlation coefficient value is positive at 0.728 , so it can be concluded that the direction of the two variables is unidirectional, which means that if consumer confidence increases, buying interest will also increase. The correlation coefficient value of 0.728 indicates the influence of the two variables has a strong influence.
\end{abstract}

Keywords: Consumer Trust, Buying Interest

\section{INTRODUCTION}

Technology is increasing very fast which causes many changes in human life. In this era, the business world is experiencing very close competition because sophisticated technology will help people to do everything. Currently, marketing in business online is increasingly needed, one of which is through the internet. With the internet, it is easier for someone to do everything and one of them is shopping online, therefore Indonesia is 
experiencing an increase.

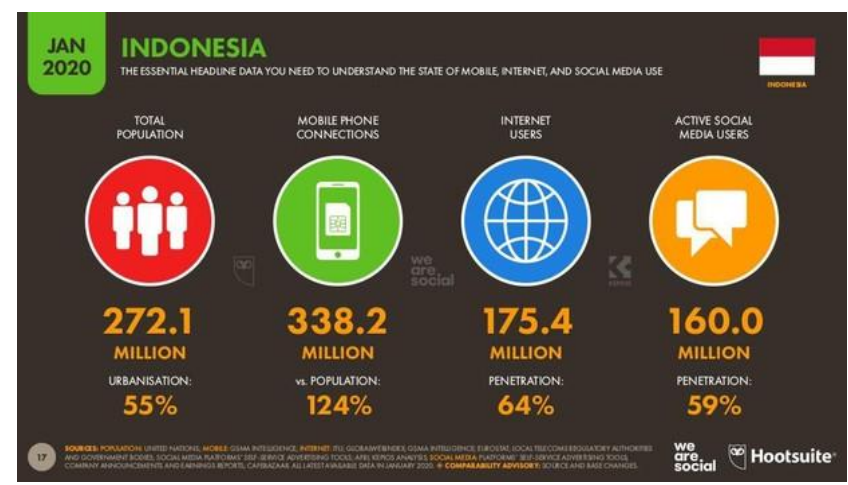

Picture 1. Internet User Data in Indonesia, January 2020

Source: detikinet.com.

Based on the table obtained in January 2020, there were 175.4 million internet users in Indonesia. Based on the total population in Indonesia reaching 272.1 million, then around $64 \%$ of the citizens in Indonesia have used the internet. Likewise, active users of social media reached 160 million. The use of the internet today is not only used by someone to dig up information and communicate but can be used for economic activities. Usually, someone makes a purchase offline by meeting directly between the seller (seller) and the customer (buyer) but now someone can make purchases online with media mobile.

One application of technology in business competition online is by using electronic commerce (e-commerce). E-commerce in Indonesia is developing quite fast, this can be seen by the number of e-commerce that has started to emerge such as Shopee, Lazada, Tokopedia, Bukalapak, which are part of e-commerce and cause the growth of interest in buying shopping online. The growth of e-commerce is getting faster from year to year. All buying and selling activities carried out on the internet now do not require face-toface contact between sellers and buyers.

Shopee is a store online that offers to buy and sell products easily and quickly. Shopee makes it easy for sellers and consumers to interact through its live chat feature. Shopee offers a variety of products ranging from Fashion products to daily necessities, Shopee comes in the form of a web application that can be opened via a Smartphone to make it easier for every user to carry out shopping transactions online, not having to go through a website on a computer anywhere and anytime for purchase.

Buying interest at shopee is very diverse, starting from the incompatibility of the quality of the goods displayed with the goods received by consumers, consumers also feel disapproved of the provisions for free shipping throughout Indonesia but in fact, consumers still pay shipping costs so that consumers feel cheated by what has been done. submitted by the shopee, as well as distrust with the guarantee of the transactions made and the disappointing quality of the goods. 
A person's buying interest can be seen through the size of the consumer's desire to make shopping online the main goal for making transactions, seeking in-depth information about a product or having an interest in shopping online rather than shopping offline.

Simamora (2011:106) suggests that buying interest will arise if consumers have confidence in the goods that cause someone to be interested in buying. However, if consumers have a strong buying interest without any vigilance in conducting transactions, it will result in fraud or so which can harm the customer. This is because there is no direct face-to-face with the seller so that consumer trust becomes the main capital in conducting transactions.

The results of research that has been carried out by Dillah (2019) show that the company's image and customer trust have a significant effect on buying interest, having a value of $32.8 \%$. According to research conducted by Hana (2019), interest has an influence on purchasing decisions of 0.606 . This means that the younger generation has an interest in making purchases online based on the level of trust and the quality of the services offered.

If consumer trust is low, consumers will have a fear if the goods to be purchased does not match what they have in mind. Meanwhile, if consumer trust is high, then there will be no bad thoughts about the goods that have been purchased. Lack of trust in making purchases online can prevent consumers from participating in transactions online. Lack of trust can also be influenced by experience, product delivery problems (delays, items that don't arrive), items that don't fit, the environment, or friends who tell stories of bad experiences when making transactions that will create a sense of distrust in $e$-commerce.

\section{METHODS}

A method that researchers use in this study is to use a quantitative approach. This research was conducted to test or determine the influence between two variables, namely the trust variable and the buying interest variable. The sampling technique used in this research is non-probability sampling.

Researchers in this study used the incidental sampling technique. Researchers in this study conducted data collection through a questionnaire (questionnaire). The type of scale used in data collection in this study is the Likert scale. This scale consists of four answer choices, namely Very Appropriate (SS), Appropriate (S), Not Appropriate (TS), and Very Disagree (STS).

\section{DISCUSSION}

a. Buying interest

Kotler and Keller (2016:137) interest (interest) is conceptualized as a condition where consumers do not take any action that will be used as the basis for predicting 
behavior or action. Buying interest is a consumer behavior that appears in response to objects that have a desire to make transactions. With an interest in buying, consumers will give a positive response to the product being offered by the seller. Setiadi (2011:216) states that "buying interest is formed from consumer behavior towards branded and quality products that are trusted so that consumers have the desire to own them. While Assial argues that "buying interest is someone who wants to have a certain product or arises a desire to buy which is measured by a high level of desire to buy" Priansa (2017:163). In terms of buying interest, it is the attitude of consumers in buying a product that is likely to be purchased by someone.

b. Aspects or Indicators of Buying Interest Buying Interest in this study is a person's plan to buy a product in a certain amount and time. The stages to determine buying interest that encourages individuals to make transactions for the products offered. According to Kotler and Keller (2010) and Ferdinand in Morissan (2010: 181), the aspects of buying interest are as follows:

1) Transactional interest.

Transactional interest is an act of consumers to always buy goods or services obtained from e-commerce or a company. Transactional interest is based on a good trust in a company or e-commerce.

2) Referral interest.

Referential interest is something that consumers do to always recommend products that have been purchased to others. With this interest, the customer will have an experience with the product that has been purchased.

3) Preferential interest Preferential Interest is a behavior carried out by customers who have a primary preference for products that are considered appropriate and good by customers.

4) Exploratory interest.

Explorative interest is a behavior of customers who are always looking for positive information about the product or item that is in demand.

c. Interest factor.

Buying interest arises because there are several factors that encourage an individual that can influence buying interest. The following are several factors that can influence buying interest according to Ujito and Abdurachman (2004), namely as follows:

1) Quality: a symbol associated with the quality of a product or the physical aspect of the desired product.

2) Brand: non-material factor, namely emotional satisfaction.

3) Packaging: Packaging or packaging of a product used in selling a product or goods. 
4) Price: Consumer sacrifices in the form of material factors that must be given in order to get a certain product.

5) Availability of goods: a consumer action on the availability of products on the market.

6) Reference: A thing that affects consumer stimulus that comes from outside or inside when choosing a product so that it can be used as a media for promotional material.

d. The stages of buying interest

The stages of buying interest are used by researchers to select subjects in buying interest, namely: the stages of attention, interest, desire, and action. The stages of producers to form buying interest or consumer encouragement for the products or services offered can be seen from several concepts developed by Kotler and Keller (2016: 568) from AIDA, namely:

1) Attention.

At this stage, the stage where we will determine how to evaluate an item or service that is in accordance with what the wants customer. at this stage candidates' customers already reviewing the well, a product or service is offered.

2) Interests.

At this stage, prospective customers will buy the goods or services offered after consumers seek information about the details of the goods that have been offered.

3) Desire.

At this stage, potential customers begin to think about the goods or services offered to grow interested in buying. At this stage, it can be marked by strong interest from the customer to buy a product that is being offered.

4) Actions.

At this stage, the customer already has high stability to buy the product or service that has been offered.

e. Measuring buying interest

Looking at the research researched by Schiffman and Kanuk (2009) and the results of research from Widjajanta (2016), namely buying interest can be measured based on the following things:

1) There is an interest in obtaining information about a product, a brand, or a service.

2) There are considerations to buying a product.

3) There is a sense of interest in trying to buy a product.

4) There is a sense of wanting to know more about a product.

5) Want to own the product. 


\section{b. Consumer Trust}

In e-commerce, trust is a major part of converting visitors into buyers. When shopping online, customers rely on promises that have been given by the seller. For example, a customer will not know if the product that has been purchased will be as expected, the customer must also believe that the personal information that will be provided to the seller will not be misused and the transaction must be safe and free from fraud.

Kotler and Keller (2016: 225) state that "trust is the willingness of $e$-commerce to outperform business partners. This is related to a number of interpersonal and interorganizational factors, such as perceived competence of the company, integrity, honesty, and benevolence". According to Mowen (2012:312) consumer trust is "all knowledge possessed by customers and all conclusions made by customers about objects, attributes, and benefits.

According to Mayer "Trust is the willingness of a party to trust another party which has been based on the expectation of the other party who will take certain actions that are important to the party who believes in him. Trust is a complex multidimensional construct that can be influenced in different ways from different beliefs" Susanti and Hadi (2013).

\section{Components and Indicators of Trust}

McKnight and Chervany (2002) say in their research that trust is a very broad design. The components of trust that must be considered according to McKnight \& Chervany (2002) are divided into several points, namely:

1. Integrity, is the ability to keep promises from the seller. This integrity reflects how the behavior or expertise of the seller. Integrity indicators can be seen from the point of view of openness, fulfillment, loyalty, honesty, relevance, and proficiency.

2. Benevolence (kindness), is the motivation and attention of the seller to do something in accordance with the interests of consumers. Benevolence is the seller's willingness to provide satisfaction for mutual benefits between sellers and consumers. In this case, the seller is not just pursuing profit but paying attention to meeting customer satisfaction. Indicators of kindness include caring, empathy, confidence, and acceptance.

3. Competency, is the ability of the seller to provide the needs that have been desired by the customer. This means that the seller must be able to provide, serve, and secure transactions from interference from other parties. Consumers get a guarantee of satisfaction and security from the seller when the transaction is carried out. The indicators consist of experience, institutional approval, and ability in science.

4. Predictability, can be interpreted as the consistency of behavior by the seller. The ability of the seller to provide certainty about the goods or products being sold so that consumers can estimate and predict the ability of the seller. The indicators include 
the self-image of the seller, predictable risk, and consistency. Various indicators above that can affect consumer buying interest.

Research conducted by McKnight and Chervany is also discussed by Mayer, et al who also developed a model of the dimensions of trust, namely:

a. Ability

Ability is a group of skills, competencies, and characteristics that allow one party to have a specific domain. Ability is not just a service with a consumer but more on the aspect of how one can do business.

\section{b. Benevolence}

Benevolence is the extent to which the trustee wants to do and give the best to the trustor. Benevolence is the basis of social networking services because benevolence will create positive relationships between individuals.

\section{c. Integrity}

Integrity is the perception trustor's that the trustee will stick to a set of principles that have been given to the trustor. The trustee's words submitted to the trustor must be the same as the actions taken by the trustee and consumers have a desire whether the trustee can do something commensurate with what has been promised (Susanti, 2013).

\section{Dimensions of Trust}

Rawlin states that the dimensions of trust are divided into several parts, namely:

1. Satisfaction.

Providing the best for consumers to feel satisfied and will create a good experience. Consumer satisfaction is a mediator variable that connects the variables of service quality, trust, and consumer loyalty.

2. Interpersonal Scale.

This scale is used to measure the relationship between an individual and another individual who is in his or her field well. Interpersonal relationships can also be referred to as good relationships between business people and customers.

3. Trusted.

Trustworthiness relates to consumer confidence in the goodness of ability, honesty, integration of reliability, and sincerity in the services provided.

\section{Trust Results.}

Trust must lead to consumer commitment behavior so that they continue to make repeat purchases (Priansa, 2017: 123). 


\section{c. e-commerce}

Kotler (2008:132) concludes "e-commerce means a company or site offering to transact or facilitate the sale of products and services online". E-commerce is the purchase of goods or services made through a network with specific methods designed to receive or place orders. The goods or services that have been ordered, payment or delivery does not have to be done online" (statistics e-commerce 2020).

According to Mowen (2012:312), consumer trust is "all knowledge possessed by consumers and all conclusions made by consumers about objects, attributes, and benefits". E-commerce has become a very important part of the performance or management of a business that can generate added value and a significant level of efficiency within a company. Pangestu's research (2015) states that site applications $e$ commerce involve two sides, namely:

1. Server side.

The server is a party that also provides various types of services, in the form of accessing files, peripherals, databases, which will then be connected to their clients, namely sellers and customers.

2. Client-Side.

In the context of e-commerce, clients are sellers and customers who use and utilize services from server and client terminals in the form of computers, smartphones, and other equipment that provides communication.

\section{Implementation of technology e-commerce}

Traver \& Laudon (2016: 53-56) gives the category into eight unique identities of the application of technology e-commerce is as follows:

\section{Ubiquity}

technology e-commerce is a technology that is always available in all places and at all times. This is one thing that distinguishes e-commerce from traditional trading systems where traditional trade requires a definite place and buying and selling activities occur only within a certain time.

\section{Global Reach}

technology E-commerce, there is no prohibition on buying and selling transaction 
activities even though there are things that distinguish sellers and consumers such as cultural differences and others. In addition, in this case, activities e-commerce can be carried out without regional and national boundaries and have a price comparison with traditional trade, of course, e-commerce has a more effective price. And of course, the total number of consumers in this business can be counted.

\section{Universal Standards}

technology implementation standards E-commerce is universal in the world. This is different from traditional trade where there will be various differences that can be found in different regions or countries.

\section{Richness}

In technology e-commerce, there is product information that is more complex, detailed, and also varied which of course makes potential consumers more interested in making transactions compared to products or goods traded in all traditional markets.

\section{Interactivity}

Communication technology provided by parties e-commerce that makes the interaction between sellers and consumers, so that the question and answer process about the description of a product will be easy to do so that product information can be more easily obtained.

\section{Information Density The}

technology provided by e-commerce can reduce processing, storage, and communication costs which make the prices of products sold cheaper and improve the quality of available information, both the amount of product stock, timeliness of delivery, and the truth of product information with the correctness of the product. the.

\section{Personalization and customization}

Available technology allows users to e-commerce personalize messages to be delivered to individuals, everyone, or certain groups. Thus, targeting of marketing messages, both promotional and other to specific individuals, can also be done to other individuals or groups by adjusting the message to the name, desired destination, and purchase history that has occurred. As for Customization itself, it is changing the 
delivered product or service based on previous choices or activities.

\section{Social Technology}

Social technology is a technology that helps users to improve their communication and socialization skills by providing information sharing with communities or virtual world groups.

\section{Types of e-commerce}

Of the various types for activities e-commerce that occur, Traver \& Laudon (2016:57-60) then distinguishes into the following categories:

\section{E-commerce Business to Consumer}

This type is a very common type and is usually carried out in the business of selling from an e-commerce to a customer.

2. E-commerce Business to Business

This type is the type that makes sales online from e-commerce to other e-commerce.

3. E-commerce Consumer-to-Consumer

This type is the type that sells online from customer to customer.

4. E-commerce SocialSocial

e-commerce is the type that causes social networks and social relationships online.

\section{Mobile E-commerce}

Mobile e-commerce is the type that causes transactions online via mobile (Iphone, Android, Blackberry).

6. E-commerce Local

E-commerce is a type that focuses on relationships with customers based on geographic location in the area customers.

\section{RESULT}

In this study, researchers obtained the results of the spearman rank test with a sig value. (2-tailed) of $0.000<0.05$, it can be concluded that the consumer confidence variable has a significant influence on the buying interest variable $0<0.05$, so it can be concluded that the buying interest variable has a significant effect. The correlation coefficient value is positive at 0.728 , so it can be concluded that the direction of the two variables is unidirectional, which means that if consumer confidence increases, buying interest will also increase. The value is 
correlation coefficient 0.728 , so it can be concluded that the level of influence of the two variables (consumer trust with buying interest) has a strong influence. So it can be said that $\mathrm{Ha}$ is accepted and $\mathrm{H} 0$ is rejected.

\begin{tabular}{llllllll} 
& \multicolumn{9}{c}{ Descriptive Statistics } \\
& $N$ & Range & Minimum & Maximum & Mean & Std. Deviation & Variance \\
\hline kepercayaan konsumen & 97 & 69 & 68 & 137 & 102,41 & 10,169 & 103,412 \\
minat beli & 97 & 86 & 52 & 138 & 99,60 & 11,581 & 134,118 \\
Valid N (listwise) & 97 & & & & & &
\end{tabular}

Based on the table above, it can be seen that there are 12 respondents with high consumer confidence having a percentage of $12 \%$, while respondents with a moderate level of consumer confidence amounted to 85 people with a percentage of $88 \%$, it can be concluded that students majoring in FEB, FKIP, Psychology have the most consumer confidence at the moderate level.

\section{CONCLUSION}

Based on the research data, it can be concluded as follows:

a. test results from Spearman rank with sig. (2-tailed) of $0.000<0.05$, it can be concluded that the consumer confidence variable has a significant influence on the buying interest variable $0<0.05$, so it can be concluded that the buying interest variable has a significant effect. The correlation coefficient value is positive at 0.728 , so it can be concluded that the direction of the two variables is unidirectional, which means that if consumer confidence increases, buying interest will also increase. The value is correlation coefficient 0.728 , so it can be concluded that the level of influence of the two variables (consumer trust with buying interest) has a strong influence. So it can be said that Ha is accepted and $\mathrm{H} 0$ is rejected.

b. The researcher concludes that $\mathrm{Ha}$ is accepted and $\mathrm{HO}$ is rejected, which means that there is a significant influence between the variables of consumer confidence in e-commerce shopee on shopping buying interest online.

\section{Suggestions \\ for Institutions}

Researchers want to give advice on how to increase interest in buying shopping online on e-commerce shopee:

a. Research suggestions for agencies, namely in an effort to increase buying interest, shopee can provide various kinds of promotions, both free shipping, discounted prices or other bonuses which of course can attract consumers to buy something will increase. However, if the promotional ad does not display excessive notifications because based on the results of research by researchers if shopee raises a lot of notifications, it can actually make consumers or customers feel uncomfortable and ignore the promotional advertisement.

b. It is advisable for e-commerce shopee agencies in an effort to increase consumer confidence in accordance with the results of the researchers, namely so that the agency maintains the quality of the application in terms of shipping goods. According to researchers e-commerce, 
they can respond to this by accelerating the response in responding to the return of customer goods so that consumer confidence continues to increase.

\section{For Consumers}

In addition to suggestions to increase buying interest, researchers also want to provide advice on how to increase consumer confidence, which is as follows:

a. For consumers, be smart buyers, that is, before making a transaction, know in advance the transaction systems provided by the e-commerce shopee agency. . Learn and understand both the various types of transactions and obstacles that can occur and what steps or actions must be taken so that if these obstacles or difficulties do occur, we as consumers or customers are already focused on what to do. If you understand, the transaction will be safe and reliable.

b. consumers or customers e-commerce Shopeeif they find notifications from the application, do not immediately delete them from the notification because it could be that the notification provides benefits, both important information and other promotions that can actually provide benefits for e-commerce Shopee users.

\section{For further}

researchers, it is hoped that further research can further refine some of the weaknesses in this study. Suggestions for further researchers are expected to be able to explore more about consumer trust and its influence with other things because considering that there are several factors that influence buying interest in addition to consumer trust factors. 


\section{REFERENCE}

Ardyanto, D.(2015). Pengaruh Kemudahan dan Kepercayaan e-commerce terhadap Keputusan pembelian IonlineI(Survei pada konsumen www.petersaysdenim.com). Jurnal Administrasi Bisnis.

Azwal Haekal, Bambang Widjajanta, 2016, Pengaruh Kepercayaan dan Persepsi Resiko Terhadap Minat Membeli Secara Online pada Pengunjung Website Classifieds di Indonesia, Journal of Business Management and Enterpreneurship Education, Vol.1, No.1, April.

Bakti, U., \& Septijantini Alie, M. (2020). Pengaruh Kualitas Pelayanan, Produk dan Harga Terhadap Minat Beli Pada Toko Online Lazada di Bandar Lampung. Jurnal Ekonomi, 22(1), 18. https://mediakonsumen.com/2018/05/14/sur.

https://databoks.katadata.co.id/datapublish/2020/07/06/pengunjung-situs-shopee-terbesar-diindonesia. Diakses pada tanggal 09 Maret 2021 pukul 10:21.

Iprice. Peta E-commerce Indonesia. Diakses pada tangga 01 Juni 2021 pukul 15:06. httpss://iprice.co.id/insight/mapofecommerce/en/

Hamdani, Trio. 2019 Hasil Survei: Orang Indonesia Belanja Online 5 Kali/Bulan. detikFinance. Diakses pada tangga 15 Juni 2021 pukul 15:08. https://finance.detik.com/industri/d4805460/hasil-survei-orang-indonesia-belanja-online-5-kalibulan/2

Haryanto, Agus Tri. 2020."Riset: Ada 175,2 Juta Pengguna Internet di Indonesia". https://inet.detik.com/cyberlife/d-4907674/riset-ada-1752-juta-pengguna-internet-diindonesia. Dikutip pada tanggal 15 juni 2021 pukul 13: 24.

https://shopee.co.id.

Kusumawati, Saifudin.2020. Pengaruh Persepsi harga dan Kepercayaan terhadap Minat Beli secara online saat pandemi Covid-19 pada Masyarakat Milenial di Jawa Tengah. Jurnal Administrasi Bisnis. 6. No 1. Juni 2020.

Kusumatrisna, Adam Lutfi, dkk. 2020. Statistik E-commerce 2020. Badan Pusat Statistik. ISSBN: 978-602-360-2.

Kim, D. J., Ferrin, D. L., \& Rao, H. R. (2008). A trust-based consumer decision-making model in electronic commerce: The role of trust, perceived risk, and their antecedents. Decision Support Systems, 44(2), 544-564. doi:10.1016/j.dss.2007.07.001 
Kotler, P., \& Kevin, K. L. (2016). Marketing Management 16 edition. New Jersey: Pearson.

Kotler, P., \& Keller, K. L. (2009). Manajemen pemasaran Jilid 1. In Jakarta (13th ed).

Kotler, Philip, Gary Amstrong. 2008. Prinsip-Prinsip Pemasaran, Principles of Marketing. Edisi 12 Jilid 1. Jakarta: Penerbit Erlangga.

Kotler, P., \& Kevin, K. L. (2016). Marketing Management 16 edition. New Jersey: Pearson.

Schiffman, \& Kanuk, (2015). Consumer Behavior. 11th Edition. Global Edition.

Kinnear, Thomas C and James R Taylor. 1995. Marketing research: An Applied Approach. Kinnear, Thomas C dan James R Taylor. 1995.Marketing research: An Applied Approach. 5th edition. USA.

Mowen, J. C., \& Micheal, M. (2012). Perilaku Konsumen. Jakarta: Erlangga.

Maharama, A. R., \& Kholis, N. (2018, Juli). Pengaruh Kepercayaan, Kemudahan Dan Persepsi Risiko Terhadap Keputusan Pembelian Jasa Gojek Di Kota Semarang Yang Dimediasi Minat Beli Sebagai Variabel Interventing. EKOBIS, Vol.19, No.2, 204-203.

McKnight, D.H. dan Chervany, N.L. (2002). What Trust Means In E-commerce Customer Relationships: An Interdisciplinary Conceptual Typology. International Journal of Electronic Commerce, Vol. 6 No. 2, hal 35-59.

Morissan. 2010. Periklanan komunikasi pemasaran terpadu Jakarta: KENCANA Prenamedia Group.

Priansa, D. J. (2017). Perilaku Konsumen Dalam Persaingan Bisnis Kontemporer. Bandung: Alfabeta.

Setiadi Nugroho J. 2011. Perilaku Konsumen: Konsep dan Implikasi untuk Strategi dan Penelitian Pemasaran. Prenada Media. Bandung.

Susanti, V., \& Hadi, C. (2013). Kepercayaan Konsumen dalam Melakukan Pembelian Gadget Secara Online. Jurnal Psikologi Industri dan Organisasi, 02.

Rahayu, Ning. 2019. Pertumbuhan E-commerce Pesat di Indonesia. Warta Ekonomi.co.id. https://www.wartaekonomi.co.id/read216302/pertumbuhan-e-commerce-pesat-diindonesia. Diakses pada 15 Juli 2021 pukul 14:20.

Rahayu, Martha. 2019. Berlomba Memimpin Pasar E-commerce Indonesia. Diakses pada tanggal 15 Juli 2021 pukul 14:44. https://swa.co.id/swa/trends/berlomba-memimpin-pasar-ecommerce-indonesia 
Rahayu, Eva Martha. 2019. Pesatnya Pertumbuhan E-commerce Pacu Ekosistem Pembayaran Digital. www.swa.co.id. https://swa.co.id/swa/trends/pesatnya-pertumbuhan-e-commercepacu-ekosistem-pembayaran-digital. diakses pada tanggal 16 Juni pukul 14:40.

Reza, Jecko Iqbal. 2015. Shopee, Aplikasi Belanja Online C2C Meluncur Di Indonesia. Liputan 6.Com. Diakes pada tanggal 2 Desember. Pukul 22:41.

Sitorus, S. D., \& Mawardi , M. K. ( 2019, Agustus). Pengaruh Persepsi Kemudahan, Persepsi Risiko, Dan Kepercayaan Konsumen Terhadap Minat Beli Online (Studi Pada Mahasiswa Pengguna Aplikasi Jual Beli Online Carousell). Jurnal Administrasi Bisnis (JAB), Vol. 73 No. 1, 141-150. Diambil kembali dari administrasibisnis.studentjournal.ub.ac.id.

Simamora, B. 2011. Memenangkan Pasar dengan Pemasaran Efektif dan. Profitabel. Jakarta: Gramedia Pustaka Utama.

J, Setiadi Nugroho (2011). Perilaku Konsumen: Konsep dan Implikasi untuk strategi dan Penelitian Pemasaran. Prenada Media. Bandung.

Traver \& Laudon. (2016). E-commerce : Business,Technology, Society. Global Edition. Twelfth Edition. Edinburgh Gate : Pearson Education.

Ujianto, U \& Abdurachman, A. (2004). Analisis Faktor-faktor yang Menimbulkan Kecendrungan Minat Beli Konsumen Sarung ( studi perilaku konsumen sarung di Jawa Timur). Jurnal Manajemen dan Kewirausahaan. 6(1), 34-53 